\title{
الافتتاحية
}

\section{الأهن والتنمية بين شرق آسيا وغربها}

\section{بقلم}

الأستاذ/ ضياء رشان المان

رئيس الهيئة العامة للاستعلاهات

تثبير المقارنة بين شرق آسيا وغربها إلى فروق كبيرة رغم أنهما فى قارة واحدة.

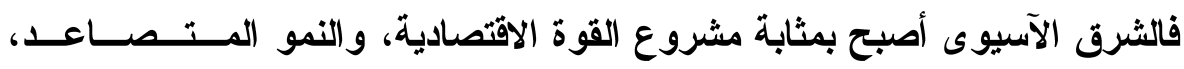
والتطور التكنولوجى، والتعاون الجماعى فى أطر عديدة لتبادل المنافع بينما مـــــزال

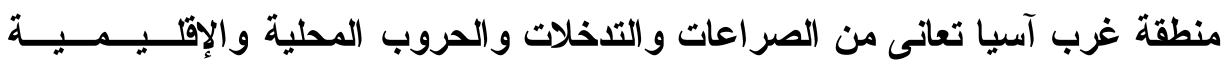
وساحة لمنافسات القوى الكبرى رغم ثراء غرب آسيا بكل أنواع الموارد الطبيــــــة و البشرية أكثر من شرقها.

ويكمن السبب الأساسى فى ذللك، فى فقدان الأمن والاستقرار فى منطقة غرب آسيا،

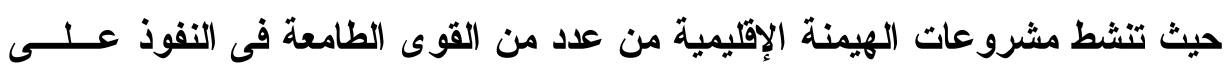

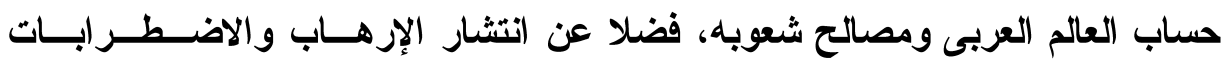
الاخلية فى أكثر من دولة.

منطقة شرق آسيا بدورها كاتت قد مرت بظروف مماثلة لاكثر من نصف قرن، مسن تفكك وحروب كبرى حيث دارت على ارضها فصول مرعبة من الحربين العالمـــــــن الاولى والثانية، ثم الحرب بين الكوريتين الاولى والثانية، ثم الحرب الفيتنامية وحروب كمبوديا والحرب الطبقية الهندية وغيرها. ولكن، ما أن تخلصت دول الثرق الآسيوى من هذه الحروب والاضطر ابــات، وتـــ 


\section{6}

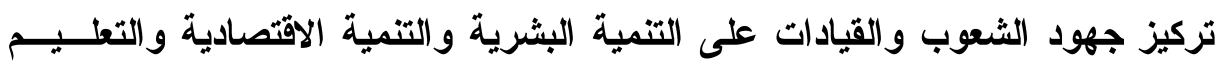

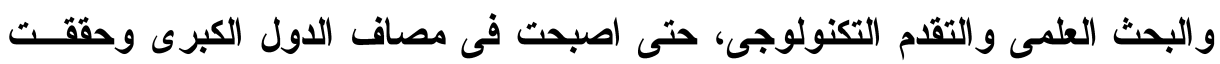
الرخاء لثنعوبها.

من هذه المقارنة تبدو حاجة منطقة غرب آسيا والثرق الأوسط للاهـن و السـلام

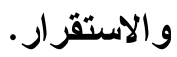

ومن هذا المنطق تبدو أهمية الدور التاريخى الذى تقوم به القيادة المصرية .

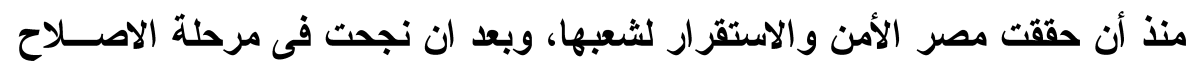
الاقتصادى وتحولت إلى نهضة شاملة وانطلاق فى كل المجالات، حتى بدأت فى بـــــل الجهود من اجل احتواء الأزمات فى منطقة غرب آسيا والثرق الأوسط وأفريقيا.

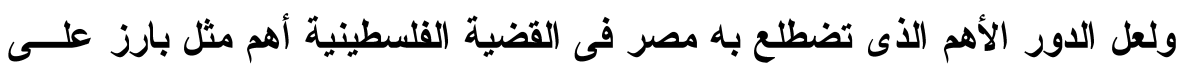

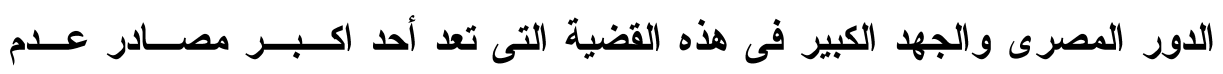

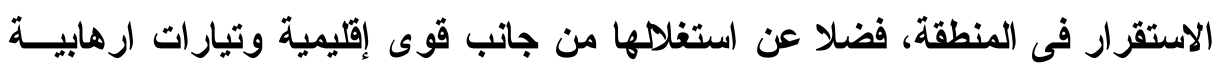
لتظذية العنف و التطرف فى المنطقة.

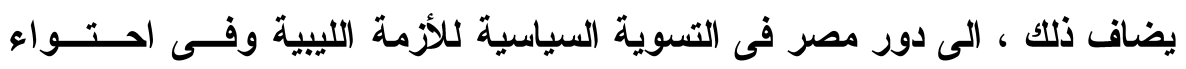

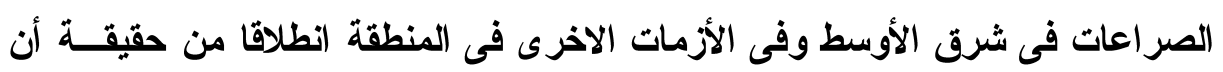

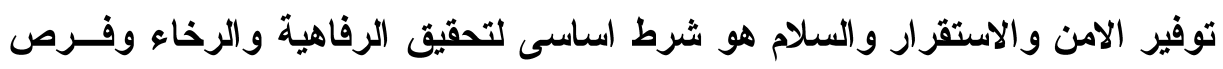

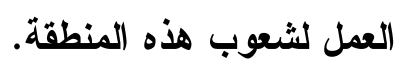

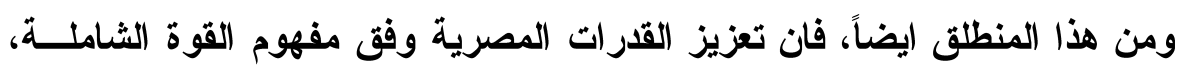

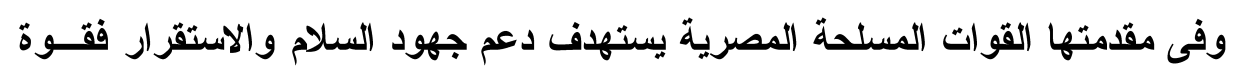

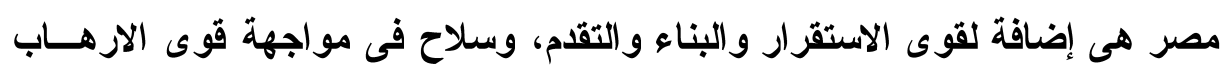

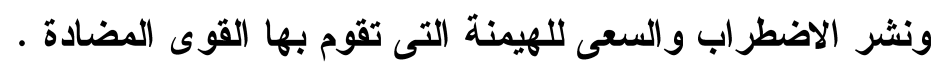

